\title{
Flexible options to provide energy for capturing carbon dioxide in coal-fired power plants under the Clean Development Mechanism
}

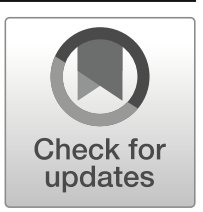

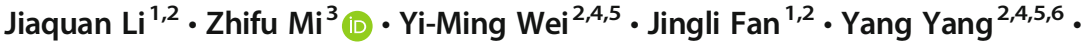 \\ Yunbing Hou ${ }^{1}$
}

Received: 7 October 2018 / Accepted: 14 March 2019/Published online: 10 April 2019

(C) The Author(s) 2019

\begin{abstract}
Operators of coal-fired power plants with carbon dioxide capture and storage (CCS) can provide energy for carbon dioxide $\left(\mathrm{CO}_{2}\right)$ capture by increasing coal input (option i) or reducing electricity output (option ii). Under the Clean Development Mechanism (CDM), does a flexible option exist in the future to provide energy for capturing $\mathrm{CO}_{2}$ ? In this study, we use a representative coal-fired power plant in China (600 MW) as a case study to assess the options to be implemented and the corresponding economic performance and emission reductions of coal-fired power plants with CCS. Both Monte Carlo simulation and the net present value (NPV) methods are used in this study. The results show that the flexible options yield an average NPV that is 57.36 and 48.07 million Chinese Yuan more than the net present values of option i and option ii, respectively, during three crediting periods. Additionally, the implementation of flexible options can improve the emission reduction effect in coal-fired power plants with CCS and promote the optimization of power systems. The priority for expanding the positive effects of flexible options is for international climate change policy negotiators and policymakers to formulate stricter international emission reduction policies with a high certified emission reduction price. In addition, a good communication and coordination mechanism between the coal-fired power plants and the administration of the power system are required to ensure the efficient implementation of flexible options.
\end{abstract}

Keywords Coal-fired power plants $\cdot \mathrm{CCS} \cdot$ Flexible options $\cdot \mathrm{CDM}$

Zhifu Mi

z.mi@ucl.ac.uk

Yi-Ming Wei

wei@bit.edu.cn

Extended author information available on the last page of the article 


\section{Introduction}

The need to address climate change has reached a global consensus (IPCC 2014). Many countries have introduced regulatory policy schemes for carbon reduction (Abdi et al. 2018). However, in the foreseeable future, our world will still rely heavily on fossil energy (IEA 2016b). Carbon dioxide capture and storage (CCS) technology is a potential approach for mitigating climate change. Furthermore, without the contribution of CCS towards achieving global atmospheric carbon dioxide $\left(\mathrm{CO}_{2}\right)$ concentrations within a range from 430 to $480 \mathrm{ppm} \mathrm{CO}_{2}$ equivalent, the global emission reduction cost will increase by $138 \%$ from 2015 to 2100 (IPCC 2015). However, due to high capital, operating and maintenance costs, CCS technology is difficult to develop without the input of external income (Stigson et al. 2012). In this context, the inclusion of CCS projects under the Clean Development Mechanism (CDM) has been considered a financial incentive mechanism for developing countries that wish to deploy CCS. Participants in the United Nations Framework Convention on Climate Change Conference of the Parties, Cancun, Mexico, December 2010 decided that CCS can be developed into CDM project activities (UNFCCC 2011). The relevant methodology has been drawn up preliminarily and is being improved gradually (UNFCCC 2013). An important aspect of CDM projects is the certification of emission reductions. Similar to other types of CDM projects, the certified emission reductions (CERs) of CCS projects are equal to the difference between baseline emissions and project emissions and leakages (Global CCS Institute 2011; IEAGHG 2007; Philibert et al. 2007; UNFCCC 2013). The $\mathrm{CO}_{2}$ emissions arising from the energy (electricity and heat) used for $\mathrm{CO}_{2}$ capture $^{1}$ are the largest part of the project emissions.

As the largest $\mathrm{CO}_{2}$ emission sector in the world, the coal power industry will continue to make up the largest market for CCS technology for a long time (CoalSwarm/SierraClub/ Greenpeace 2018; IEA 2017; IPCC 2014). The additional energy required to operate a $\mathrm{CO}_{2}$ capture system in a coal-fired power plant either reduces the power output of the plant or increases the coal input (Supekar and Skerlos 2015). For coal-fired power plants operating at a high capacity factor, ${ }^{2}$ there are two options to provide energy for $\mathrm{CO}_{2}$ capture. Option $\mathrm{i}$ involves increasing the coal input: A capacity extension (i.e. a new auxiliary power plant) is implemented to provide the additional energy needed for $\mathrm{CO}_{2}$ capture (IEAGHG 2007). Option ii involves reducing the power output: The energy used by the capture system is provided by the retrofitted coal-fired power plant with no capacity extension (IEAGHG 2007). For coal-fired power plants operating at a low capacity factor, there are also two options to provide energy for $\mathrm{CO}_{2}$ capture. Option i involves increasing the coal input: The energy used by the capture system is provided by the retrofitted coal-fired power plant, resulting in a higher capacity factor (additional coal input). Option ii involves reducing the

\footnotetext{
${ }^{1} \mathrm{~A}$ CCS project consists of the following three links: $\mathrm{CO}_{2}$ capture, transport and storage. The energy consumption in $\mathrm{CO}_{2}$ transport is primarily concentrated in the booster stations, which are far from coal-fired power plants (approximately $200 \mathrm{~km}$ ) (IEAGHG 2005). In addition, the $\mathrm{CO}_{2}$ storage site is generally far from the coal-fired power plants. This study assumes that the energy needed for both $\mathrm{CO}_{2}$ transport and storage is provided by the power grid. Therefore, the energy consumption of the CCS project discussed in this study refers only to the electricity and steam used during the $\mathrm{CO}_{2}$ capture process.

${ }^{2}$ The capacity factor is the unitless ratio of the actual electrical energy output over a given period of time to the maximum possible electrical energy output over that period (U.S.NRC 2018). This definition can be expressed in the form of an equation as follows:

Capacity Factor $=$ actual output of a power plant throughout the year $(\mathrm{MWh}) /(365$ days $\times 24 \mathrm{~h} /$ day $\times$ full nameplate capacity (MW)).
} 
power output: The energy used by the capture system is provided by the retrofitted coal-fired power plant with no change in capacity factor (no additional coal input). Currently, CCS operators are interested in partial capture instead of full capture (Li 2010). In other words, the capture capacity is only enough to capture part (e.g. less than $25 \%$ ) of the annual emissions of a coal-fired power plant without CCS. Additionally, CCS operators will not capture the residual emissions of the coal-fired power plants and the emissions generated by the additional coal input. Under these circumstances, the $\mathrm{CO}_{2}$ emissions arising from the energy used for $\mathrm{CO}_{2}$ capture are different under different options.

Option i: Under option i, new auxiliary power plant (or idle generating capacity) is fully utilized for capturing $\mathrm{CO}_{2}$, thereby helping to maintain the power output. In this context, the amount of coal used in power generation is greater than that used before the $\mathrm{CO}_{2}$ capture system was installed. Therefore, other power plants in the electricity system can maintain the stability of the power system without increasing the power output. Consequently, the calculation of $\mathrm{CO}_{2}$ emissions arising from the energy used for $\mathrm{CO}_{2}$ capture should be based on the $\mathrm{CO}_{2}$ emission factors of the coal-fired power plants (IEAGHG 2007).

Option ii: Under option ii, the coal input for power generation is the same in coal-fired power plants with and without the $\mathrm{CO}_{2}$ capture system. The reduction in the power output is equal to the amount of energy consumed by the $\mathrm{CO}_{2}$ capture system. To ensure the stability of the electricity system, the reduction in the power output of retrofitted coal-fired power plants should be compensated by increases in the power output of other power plants in the electricity system. Therefore, the combined margin $(\mathrm{CM}) \mathrm{CO}_{2}$ emission factor of the electricity system should be used to calculate the total $\mathrm{CO}_{2}$ emissions arising from the use of energy for $\mathrm{CO}_{2}$ capture (Haefeli et al. 2004; IEAGHG 2007).

According to the calculation principle (UNFCCC 2015), the $\mathrm{CM} \mathrm{CO}_{2}$ emission factor of the electricity system is lower than the $\mathrm{CO}_{2}$ emission factors of coal-fired power plants. In comparison, when option $\mathrm{i}$ is executed, a larger profit can be gained from power output, ${ }^{3}$ while less profit is obtained from the Certifified Emission Reductions (CERs). Figure 1 shows some differences between these two options in detail. Therefore, based on the principle of profit maximization, does a flexible option (exploiting one of the two options that yield larger integrated profits) exist in the future to provide energy for capturing $\mathrm{CO}_{2}$ under the CDM in developing countries? In addition, how do flexible options change the economic performance and emission reduction effect of coal-fired power plants with CCS? Here we point out that the economic performance of power production in our data is expressed in the form of profit. Additionally, we assume that CER transaction is cost free to incorporate this factor into the economic performance of power production. The income from the CERs is considered profit in this study.

China, the world's largest emitter of $\mathrm{CO}_{2}$ (Mi et al. 2017a; Mi et al. 2017b), is facing huge pressure to reduce emissions. The emission reduction effect of CCS technology could be attractive to China, where the coal power industry has been and will continue to

\footnotetext{
${ }^{3}$ This study indicates that coal-fired power plants will be profitable; that is, more electricity will generate more profits. Additionally, this study assumes that the profits and losses associated with the CCS project and coal-fired power plant belong to a single enterprise.
} 


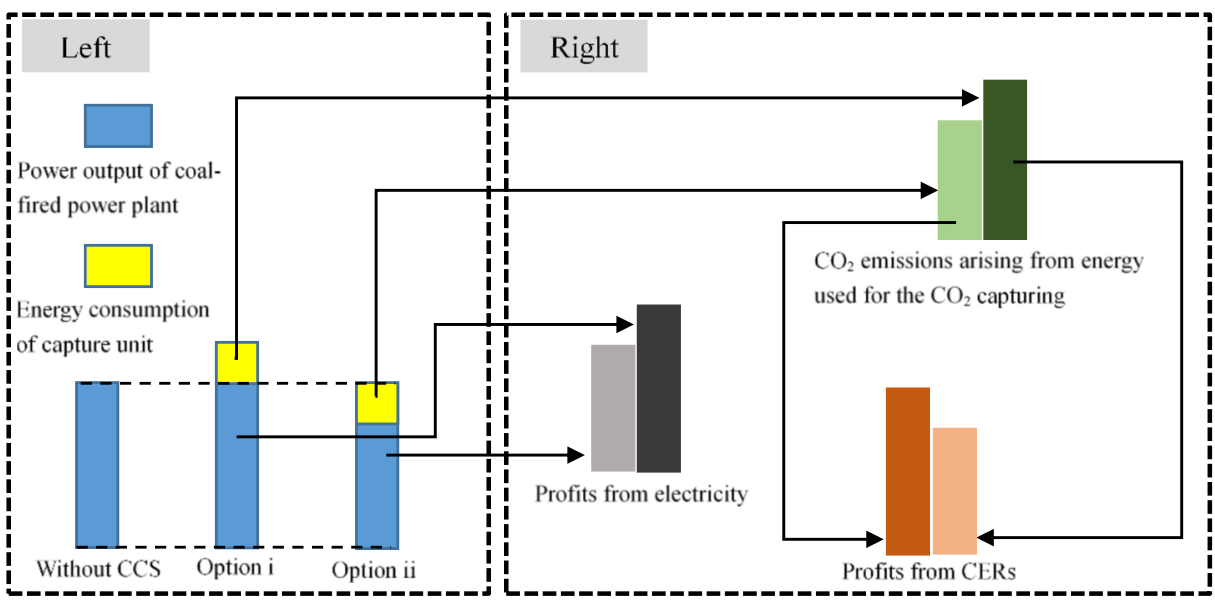

Fig. 1 Some differences between the two options. On the right side of the figure, we compare the profits from electricity, profits from CERs and $\mathrm{CO}_{2}$ emissions arising from energy used for the $\mathrm{CO}_{2}$ capture under option $\mathrm{i}$ and option ii

be the primary emissions sector (Zhang et al. 2014). Consequently, CCS technology is likely to become increasingly attractive to China's coal-fired power plants.

Therefore, based on the principle of profit maximization, we use a typical coal-fired power plant in China as a case study to assess the options for providing energy to capture $\mathrm{CO}_{2}$ under the $\mathrm{CDM}$ in developing countries and to evaluate the corresponding economic performance and emission reductions of coal-fired power plants with CCS.

\section{Literature review}

High-energy consumption is an important factor that leads to the high cost of CCS projects (Arranz 2016; IPCC 2005). In general, the energy cost accounts for approximately $8-27 \%$ of the total cost of $\mathrm{CO}_{2}$ capture (Broek et al. 2009; Company and McKinsey 2008; Viebahn et al. 2012; ZEP 2011). The purpose of an enterprise is to make a profit. The energy cost of $\mathrm{CO}_{2}$ capture is directly affected by both the amount of energy consumed and the energy price. Ziaii et al. (2009) established a dynamic rate model for the removal of $\mathrm{CO}_{2}$ from coal-fired power plants by mono ethanol amine (MEA). Based on this model, the removal rate of $\mathrm{CO}_{2}$ can be increased by $1 \%$ under the condition of reducing the steam rate (energy consumption). It is more efficient to reduce the capture cost through the flexible operation of the capture rate than by simply controlling the capture system to reduce energy consumption. Chalmers et al. (2009) evaluated the feasibility of flexible operation of the capture system and pointed out that there is no obvious technical obstacle to flexible operation. Patino-Echeverri and Hoppock (2012) concluded that whether the benefits of flexible operation outweigh the increased costs depends on the relationship between capital and operating costs and cyclical electricity price differentials. Research by Wiley et al. (2011) showed that in a market with cyclical electricity demand in New South Wales, flexible operation can capture $50 \%$ of the $\mathrm{CO}_{2}$ generated by coal-fired power plants without reducing the net amount of electricity supplied to the grid. In addition, the emission reduction cost with a 
flexible capture rate is lower than that with a fixed capture rate. The inclusion of CCS in the carbon market or the CDM is considered to be an important means to promote the development of CCS. Therefore, some studies on the CCS technology operation strategy take into account carbon prices. Based on a multiple time scale control-optimization framework, Abdul Manaf et al. (2016) evaluated the potential net operating revenue of the flexible operation of a coal-fired power plant retrofitted with a post-combustion $\mathrm{CO}_{2}$ capture plant in response to changes in power plant load, carbon prices and electricity prices. Research by Arce et al. (2012) found that application of dynamic optimization approaches to exploit the time-varying values of wholesale electricity and $\mathrm{CO}_{2}$ prices can lead to significant savings in the operating costs associated with post-combustion $\mathrm{CO}_{2}$ capture processes. This technology can reduce energy costs by $10 \%$.

Flexible capture is considered a strategy to reduce the direct cost of $\mathrm{CO}_{2}$ capture and improve the direct benefits of $\mathrm{CO}_{2}$ capture by controlling the capture rate. In fact, under the CDM, coal-fired power plants with CCS can also improve their profits by flexible options to provide energy for capturing $\mathrm{CO}_{2}$ in developing countries. This operating mode considers both the amount of power output and the CERs, which indirectly affect the economic efficiency of $\mathrm{CO}_{2}$ capture. In addition, this flexible operating mode is an important part of the comprehensive mechanism to maximize the economic efficiency of the capture system. However, this subject has not received sufficient attention and in-depth research.

The options to provide energy for capturing $\mathrm{CO}_{2}$ can be adjusted at any time during the entire service life of coal-fired power plants. Which option will be implemented depends on the power generation profit, the $\mathrm{CM}$ emission factor, emission factor of the coal-fired power plant (or new auxiliary power plant) and the CER price. After several rounds of global climate change negotiations, global climate policy remains uncertain (Wei et al. 2014). Uncertainty in global climate policy will be reflected in the CER price (Zhou et al. 2014). Thus, by what means do we judge the options in an uncertain environment? The Monte Carlo simulation (MCS) is a widely recognized, comprehensive and flexible method for analysing uncertainties (Chou 2011; Dueñas et al. 2011; Liu et al. 2017; Vithayasrichareon and MacGill 2012). Based on the distribution function of uncertainties and a large number of simulations, the probabilities of executing each option and the corresponding economic and emission reduction effects of coal-fired power plants with CCS can be obtained annually. In addition, how does the flexible option impact the overall economic efficiency of the system over entire crediting periods? The net present value (NPV) method fully accounts for the time value and has been generally favoured in practical applications (Tang et al. 2017). The combination of MCS and NPV can be used to simulate the probabilities of executing each option and the corresponding economic and emission reduction effects of coal-fired power plants with CCS in an uncertain assessment environment.

Based on a review of the literature, we state our contributions to existing knowledge. First, flexible options for providing energy to capture $\mathrm{CO}_{2}$ in coal-fired power plants are proposed under the CDM. Additionally, the critical CER prices for option adjustment and the probabilities of executing each option (option i and option ii) are discussed in detail. Finally, we analyse the economic and emission reduction effects of coal-fired power plants with CCS under each option (option i, option ii and flexible options). 


\section{Method}

\subsection{Research framework}

The object of this study is coal-fired power plants with CCS in developing countries. The research issues raised in this study are based on two premises, which should be reasonably and scientifically explained or confirmed. First, it is assumed that the CCS projects have already been developed in the CDM. This assumption is based on the following two facts: (1) participants in the Cancun climate conference in December 2010 decided that CCS can be developed into CDM project activities (UNFCCC 2011) and (2) a relevant methodology has been drawn up preliminarily and is being gradually improved (UNFCCC 2013). Second, most operators do not capture the emissions resulting from additional coal input. Thus, based on the principle of profit maximization, we assess the options for providing energy to capture $\mathrm{CO}_{2}$ under the CDM and the corresponding emission reduction effects in coal-fired power plants with CCS in developing countries. Specifically, we address the following three issues: (1) the critical CER prices for option adjustment, (2) the probabilities of executing each option (option $i$ and option ii) and (3) the economic and emission reduction effects in coal-fired power plants with CCS corresponding to each option (option i, option ii and flexible options). In addition, global strategies focusing on expanding the advantages of flexible options and avoiding the disadvantages of flexible options are proposed. The research framework is shown in Fig. 2.

\subsection{Assumptions}

(1) There is no documentation available to specify the time interval between two rounds of CER certifications and issuances. Communication with professional researchers in the CDM project verification enterprise suggests that the CERs will be certified and issued generally every half a year to 2 years. Therefore, the emission reductions in the CCS are certified and issued once a year in this study.

(2) The $\mathrm{CO}_{2}$ emission factor and profit of coal-fired power plants are two key parameters in this paper (Table 1). In many studies, the $\mathrm{CO}_{2}$ emission factor of coal-fired power plants is set as invariant (Rubin et al. 2015; Zhang et al. 2014). In addition, we cannot obtain an accurate trend regarding the profit of

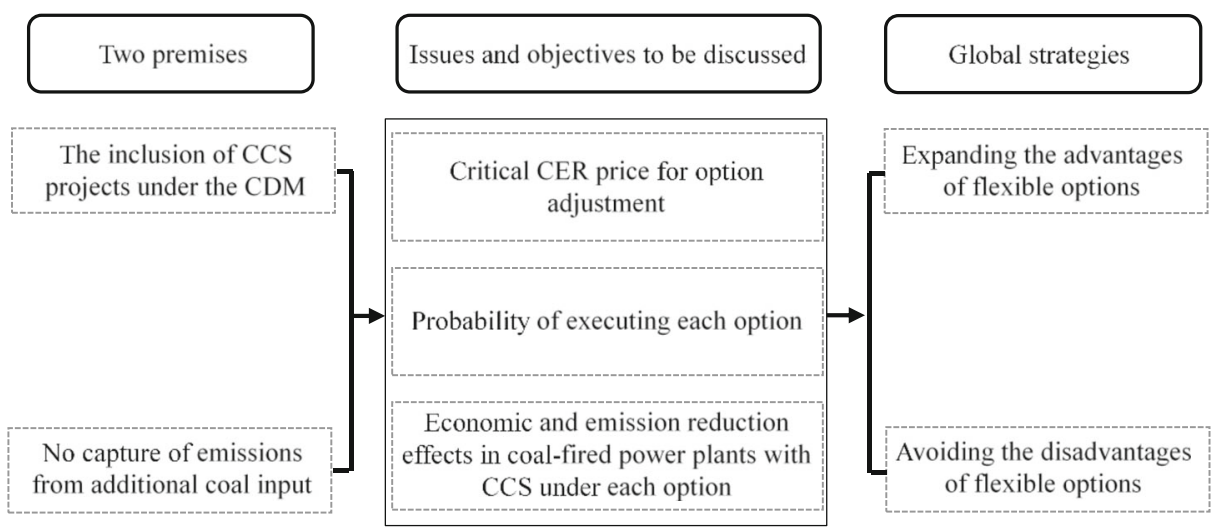

Fig. 2 Research framework 
coal-fired power plants. Therefore, the $\mathrm{CO}_{2}$ emission factor and profit of the assessed coal-fired power plant are considered invariable in this study. The subsequent sensitivity analysis will try to make up for the limitations associated with this assumption.

\subsection{Critical CER price for option adjustment and probabilities of executing each option}

The critical CER price will equalize the profits obtained by executing option $\mathrm{i}$ and option ii and is determined by profits per megawatt hour, the $\mathrm{CO}_{2}$ emission factor of the coal-fired power plant and the $\mathrm{CM} \mathrm{CO}_{2}$ emission factor of the electricity system. The probability of executing each option (option $\mathrm{i}$ and option ii) is the ratio of the number of executions of each option to the total number of simulations, and this ratio is determined by the actual CER price and the critical CER price.

$$
\left\{\begin{array}{l}
C P_{C E R . t}=\frac{p_{\text {power }}}{e f_{\text {coal }}-e f_{\text {grid.CM.t }}} \\
P R_{t}^{i i}=\frac{n_{C P_{C E R . t} \leq P_{C E R . t}}}{N} \\
P R_{t}^{i}=1-P R_{t}^{i i}
\end{array}\right.
$$

where $C P_{C E R . t}$ denotes the critical CER price for option adjustment in year $t$ (CNY (Chinese Yuan)/ton); $P R_{t}^{i i}$ is the probability of executing option ii in year $t ; P R_{t}^{i}$ is the probability of executing option $\mathrm{i}$ in year $t$; $p_{\text {power }}$ denotes the profits per megawatt hour of the assessed coal-fired power plant $(\mathrm{CNY} / \mathrm{MWh})$; ef coal denotes the $\mathrm{CO}_{2}$ emission factor of the assessed coal-fired power plant (tons/MWh); ef grid. CM. $t$ indicates the $\mathrm{CM} \mathrm{CO} 2$ emission factor of the electricity system in year $t$ (tons/MWh); $\tau 1$

Table 1 Key parameters and data affecting the flexible options

\begin{tabular}{|c|c|c|}
\hline Key parameters & Data & Data sources \\
\hline Installed capacity (MW) & 600 & / \\
\hline Annual utilization hours $(\mathrm{h})$ & 4870 & $\begin{array}{l}\text { (Editorial Board of the China Electric } \\
\text { Power Yearbook 2008-2017) }\end{array}$ \\
\hline $\begin{array}{l}\mathrm{CO}_{2} \text { emission factor of coal-fired } \\
\text { power plants (tons/MWh) }\end{array}$ & 0.821 & $\begin{array}{l}\text { (Editorial Board of the China Electric } \\
\text { Power Yearbook 2006-2017; NDRC 2014) }\end{array}$ \\
\hline $\begin{array}{l}\text { Energy consumption during } \mathrm{CO}_{2} \\
\text { capture }(\mathrm{MWh} / \text { ton })\end{array}$ & 0.306 & (Feron 2006; IEA 2008) \\
\hline Capture rate & $80 \%$ & / \\
\hline Three crediting period (years) & $3 \times 7$ & (UNFCCC 2015) \\
\hline Profits per MWh (CNY/MWh) & 26.6 & (Huaneng Power International Inc. 2016-2017) \\
\hline $\mathrm{CM} \mathrm{CO}_{2}$ emission factor (tons/MWh) & See Table 4 & Explained in the Appendix \\
\hline Initial CER price (CNY/ton) & 48.80 & (Intercontinental Exchange 2018) \\
\hline CER price volatility & 0.30 & \\
\hline CER price drift rate & 0.05 & \\
\hline
\end{tabular}


and $\tau 2$ are the starting (2018) and ending time (2038) of all crediting periods, respectively, in which $\tau 1 \leq t \leq \tau 2$ (year); $P_{C E R . t}$ denotes the CER price in year $t$ (CNY/MWh); and $n_{C P_{C E R . t} \leq P_{C E R . t}}$ is the number of times option ii is executed in year $t$. After repeated experiments, the values of the simulated variables were found to have stabilized when the number of Monte Carlo simulations (MCSs) is 10,000. $N$ is the total number of MCSs, which is set at 10000 .

\subsection{NPV of integrated profits for a coal-fired power plant with CCS under different options}

To analyse the financial/economic issues directly under different options, this study only calculates and shows the integrated profits that vary with the option adjustment. The integrated profits under option $\mathrm{i}$ refer to profits arising from power output that exceeds that under option ii and the loss of profits from CERs caused by the $\mathrm{CO}_{2}$ emissions arising from the energy used for the $\mathrm{CO}_{2}$ capture. The integrated profits under option ii refer to the loss of profits from CERs caused by the $\mathrm{CO}_{2}$ emissions arising from the energy used to capture the $\mathrm{CO}_{2}$.

$$
\begin{gathered}
\left\{\begin{array}{l}
I P_{\text {oi.t }}^{i}=v_{C O_{2}} \cdot v_{\text {power }}^{c c s} \cdot\left(p_{\text {power }}-e f_{\text {coal }} \cdot P_{\text {CER.t }}^{i}\right) \\
N P V_{I P_{\text {oi.t }}^{i}}=\sum_{t=\tau 1}^{\tau 2} I P_{\text {oi.t }}^{i} \cdot(1+\gamma)^{\tau 1-t-1}
\end{array}\right. \\
\left\{\begin{array}{l}
I P_{\text {oii.t }}^{i}=-v_{C O_{2}} \cdot v_{\text {power }}^{c c s} \cdot e f_{\text {grid.CM.t }} \cdot P_{C E R . t}^{i} \\
N P V_{I P_{\text {oii.t }}^{i}}=\sum_{t=\tau 1}^{\tau 2} I P_{\text {oii.t }}^{i} \cdot(1+\gamma)^{\tau 1-t-1}
\end{array}\right. \\
\left\{\begin{array}{l}
I P_{t}^{i}=\max \left(I P_{o i i . t}^{i}, I P_{o i . t}^{i}\right) \\
N P V_{I P_{t}^{i}}=\sum_{t=\tau 1}^{\tau 2} I P_{t}^{i} \cdot(1+\gamma)^{\tau 1-t-1}
\end{array}\right.
\end{gathered}
$$

where $I P_{\text {oi.t }}^{i}$ denotes the integrated profits in year $t$ in the $i$ th simulation when executing option i (CNY); $N P V_{I P_{\text {oi. }}^{i}}$ denotes the NPV of integrated profits in the $i$ th simulation when executing option $\mathrm{i}$ during the three crediting periods $(\mathrm{CNY}) ; I P_{\text {oii.t }}^{i}$ denotes the integrated profits in year $t$ in the $i$ th simulation when executing option ii $(\mathrm{CNY}) ; N P V_{I P_{\text {oii.t }}^{i}}$ denotes the NPV of integrated profits in the $i$ th simulation when executing option ii during three crediting periods (CNY); $I P_{t}^{i}$ denotes the integrated profits in year $t$ in the $i$ th simulation under the flexible options (CNY); $N P V_{I P_{t}^{i}}$ denotes the NPV of integrated profits in the $i$ th simulation under the flexible options (CNY); $\gamma$ denotes the discount rate; $v_{\mathrm{CO}_{2}}$ denotes the amount of $\mathrm{CO}_{2}$ captured (tons); and $v_{\text {power }}^{\text {ccs }}$ denotes the amount of energy consumed for capturing one ton of $\mathrm{CO}_{2}$ (tons/ton). 


\section{5 $\mathrm{CO}_{2}$ emissions arising from energy used for the $\mathrm{CO}_{2}$ capture under different options}

$$
\begin{gathered}
\left\{\begin{array}{l}
E_{\text {oi.t }}=v_{C \mathrm{C}_{2}} \cdot v_{\text {power }}^{c c s} \cdot e f_{\text {coal }} \\
T E_{\text {oi }}=\sum_{t=\tau 1}^{\tau 2} E_{\text {oi.t }}
\end{array}\right. \\
\left\{\begin{array}{l}
E_{\text {oii.t }}=v_{c o_{2}} \cdot v_{\text {power }}^{c c s} \cdot e f_{\text {grid.CM.t }} \\
T E_{\text {oii }}=\sum_{t=\tau 1}^{\tau 2} E_{\text {oii.t }}
\end{array}\right. \\
\left\{\begin{array}{l}
E_{\text {opt.t }}^{i}=v_{c o_{2}} \cdot v_{\text {power }}^{c c s} \cdot \text { if } \\
T E_{\text {opt }}^{i}=\sum_{t=\tau 1}^{\tau 2} E_{\text {opt.t }}^{i}
\end{array}\right.
\end{gathered}
$$

where $E_{\text {oi.t }}$ denotes the $\mathrm{CO}_{2}$ emissions arising from the energy used for the $\mathrm{CO}_{2}$ capture in year $t$ when executing option i (tons); $T E_{o i}$ denotes the total amount of $\mathrm{CO}_{2}$ emissions arising from energy used for the $\mathrm{CO}_{2}$ capture when executing option i during the three crediting periods (tons); $E_{\text {oii. } t}$ denotes the $\mathrm{CO}_{2}$ emissions arising from energy used for the $\mathrm{CO}_{2}$ capture in year $t$ when executing option ii (tons); $T E_{\text {oii }}$ denotes the total amount of $\mathrm{CO}_{2}$ emissions arising from energy used for the $\mathrm{CO}_{2}$ capture when executing option ii during the three crediting periods (tons); $E_{\text {opt.t }}^{i}$ denotes the $\mathrm{CO}_{2}$ emissions arising from energy used to capture the $\mathrm{CO}_{2}$ in year $t$ in the $i$ th simulation under the flexible options (tons); and $T E_{\text {opt }}^{i}$ denotes the total amount of $\mathrm{CO}_{2}$ emissions arising from energy used for the $\mathrm{CO}_{2}$ capture in the $i$ th simulation under the flexible options during the three crediting periods (tons).

\section{Research case and data}

\subsection{CER price volatility and drift rate}

The CERs can be traded. Based on previous research (Fuss et al. 2008; Insley 2003; Zhang et al. 2014; Zhou et al. 2010), this study assumes that the CER price exhibits random variation that follows the rule of geometric Brownian motion as follows:

$$
d P_{C E R}=\mu \cdot P_{C E R} \cdot d t+\sigma \cdot P_{C E R} \cdot d w
$$

where $\mu$ and $\sigma$ are the CER price drift rate and volatility, respectively, and $d w$ is the independent increment of a standard Wiener process.

According to Park et al. (2014), the CER futures prices from the first quarter of 2009 to the second quarter of 2017 at the Intercontinental Exchange in the EU were selected to calculate the CER price parameters, as shown in Fig. 3. The CER futures prices from the third quarter of 2011 to 2012 should not be used for reference, due to their continuous and significant decline 


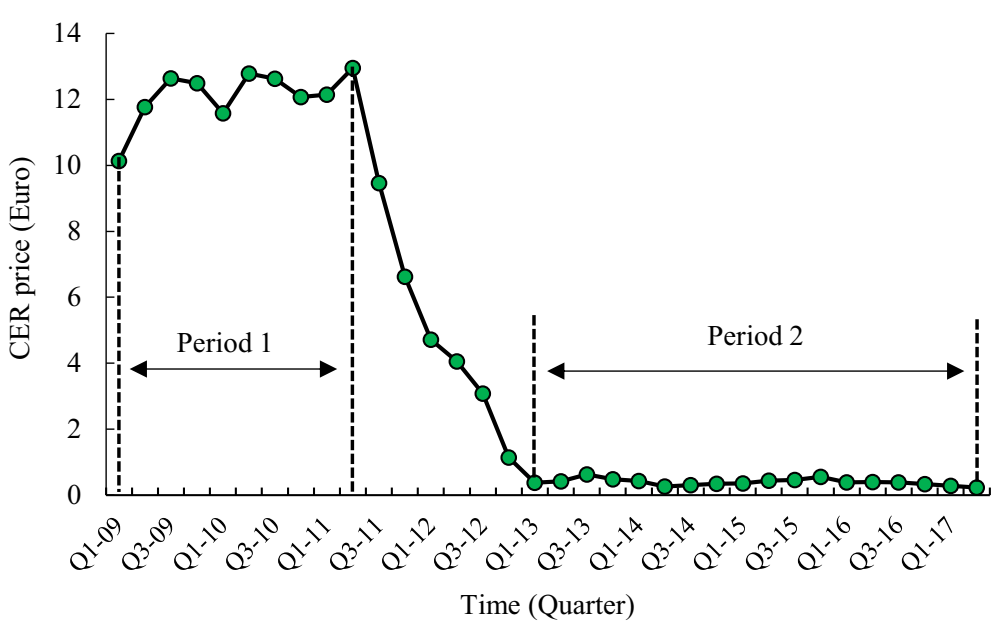

Fig. 3 CER futures prices from the first quarter of 2009 to the second quarter of 2017 at the Intercontinental Exchange (Intercontinental Exchange 2018). Period 1 indicates the time from the first quarter of 2009 to the second quarter of 2011. Period 2 indicates the time from the first quarter of 2013 to the second quarter of 2017

under the influence of various factors. Finally, the CER future prices from the first quarter of 2009 to the second quarter of 2011 and from the first quarter of 2013 to the second quarter of 2017 were selected. Due to the large difference between these two periods, the CER prices during any given period may not be representative. An eclectic approach was chosen in this study. The average of the CER prices, volatility and drift rate during the two periods were selected as the initial CER price, volatility and drift rate, respectively, and then they were converted to annual parameters, as shown in Eq. (9). In addition, the exchange rate of the Euro to the CNY was 7.80 on 29 December 2017.

$$
\left\{\begin{array}{l}
\mu=4 \cdot \mu_{1} \\
\sigma=\sqrt{4} \cdot \sigma_{1}
\end{array}\right.
$$

\subsection{Data and explanation}

This study does not employ real-world projects as references. It is assumed that the installed capacity of a coal-fired power plant is $600 \mathrm{MW}$ (megawatts). Additionally, the annual capacity factor and standard coal consumption rate of power generation are equal to those of coal-fired power plants over $6 \mathrm{MW}$ in China. The $\mathrm{CO}_{2}$ capture rate is $80 \%$. In addition, some of the data cannot be obtained directly from pre-existing research. In the following text, we explain the basis for selecting the data for some key variables in detail.

(1) The $\mathrm{CO}_{2}$ emission factor of the assessed coal-fired power plant: The net standard coal consumption rate is 0.311 tce/MWh (tons of standard coal equivalent per megawatt-hour) for coal-fired power plants with installed capacities above $6 \mathrm{MW}$ in 2018, based on the extrapolation of 2005-2016 data $\left(e f_{\text {coal }}=0.3788-0.0257 \ln (2018-2004)\right.$ ) (Editorial Board of the China Electric Power Yearbook 2006-2017). Given an emission factor of standard coal of 2.64 tons/tce (tons per ton of standard coal equivalent) (NDRC 2014), 
the $\mathrm{CO}_{2}$ emission factor of the coal-fired power plant is calculated to be 0.821 tons/ MWh.

(2) Profits per megawatt hour: This study calculated the profits per megawatt hour of coalfired power plants in China's largest power generation group, Huaneng Power International Co., Ltd., from 2015 to the first half of 2017. In the calculation, the profitability of each business segment is assumed to be the same (in which the income from the electricity and thermal business section accounts for more than $99 \%$ of the total income, and the coal-fired power business segment generates more than $94 \%$ of the total electricity) (Huaneng Power International Inc. 2016-2017). Due to fluctuations in coal prices in China, the average price over the past 3 years is taken to calculate the profits per megawatt hour, yielding a value of 26.6 CNY/MWh.

(3) $\mathrm{CM} \mathrm{CO}_{2}$ emission factor of the electricity system: China calculated the $\mathrm{CM} \mathrm{CO}_{2}$ emission factor of the electricity system in six regions (NDRC 2017). However, due to the lack of available data, in this study, China's electricity system is considered as a whole. First, we calculated the operating margin (OM) emission factor and the build margin (BM) emission factor according to the "tool to calculate the emission factor for an electricity system (version 05.0)" issued by the CDM Executive Board (CDM EB) under the United Nations Framework Convention on Climate Change (UNFCCC) (UNFCCC 2015). Then, the weighted average method was used to calculate the $\mathrm{CM} \mathrm{CO}_{2}$ emission factor of the electricity system. The percentages of the $\mathrm{OM}$ emission factor and $\mathrm{BM}$ emission factor were $50 \%$ and $50 \%$ in the first crediting period and $25 \%$ and $75 \%$ in the second and third crediting periods, respectively (UNFCCC 2015). The detailed calculation process is shown in the Appendix.

\section{Results and discussion}

\subsection{Critical CER price for the option adjustment and probability of executing each option}

The optimization of the power system structure is one of the primary directions for China to achieve low-carbon development. In the future, low-carbon energy production, including sources such as nuclear power, wind power and solar power, will develop rapidly (IEA 2016b). The $\mathrm{CM} \mathrm{CO}_{2}$ emission factor will continue to decline and will be lower than the $\mathrm{CO}_{2}$ emission factor of coal-fired power plants. In addition, the profitability of coal-fired power plants is low when the coal price is high. The critical CER price for the option adjustment is not high on the whole, with values of 98.45 CNY/ton, 56.06 CNY/ ton and 55.06 CNY/ton during the first, second and third crediting periods, respectively, as shown in Fig. 4.

The probability of executing each option (Fig. 4) is directly determined by the critical CER price and the real CER price. The global pressure to reduce emissions is increasing, and it calls for global climate negotiations to draw up more stringent emission reduction policies. However, after several rounds of global climate change negotiations, the global climate policy remains complicated (Wei et al. 2014). The CER price, which is expected to increase in value, will be fluctuated. At the beginning of the first crediting period, coal-fired power plants will basically not execute option ii because of the low CER price. However, due to the expected increase in the CER price, the probability of implementing option ii will continue to increase (from $0.05 \%$ to $21.38 \%$ ) during the first crediting 


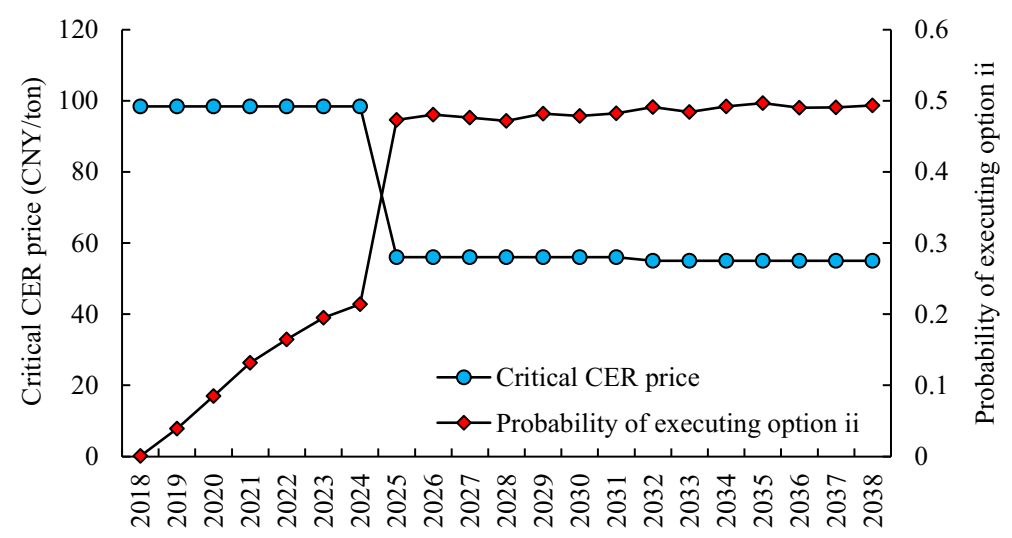

Time (Year)

Fig. 4 Critical CER price for option adjustment and the probability of executing option ii

period. The probability of implementing option ii $(47.32-49.35 \%)$ changes slightly because of the decentralized distribution of the CER price (which is determined by the principle of geometric Brownian motion) during the second and third crediting periods.

\subsection{NPV of integrated profits under different options}

The NPV of integrated profits under different options is shown in Fig. 5. In comparison to option ii, option i, with higher power generation and emission factor values, yields a broader NPV distribution. Due to the higher emission factor, the mean of the NPV under option $\mathrm{i}$ is lower than that under option ii. However, under uncertain emission reduction policy conditions (CER price), neither of their integrated profits is always larger or smaller than the other. Compared with option $\mathrm{i}$ and option ii, the flexible options yield more profits because the average NPV is increased by $34.61 \%$ (57.36 million $\mathrm{CNY}$ ) and 30.74\% (48.07 million CNY), respectively.

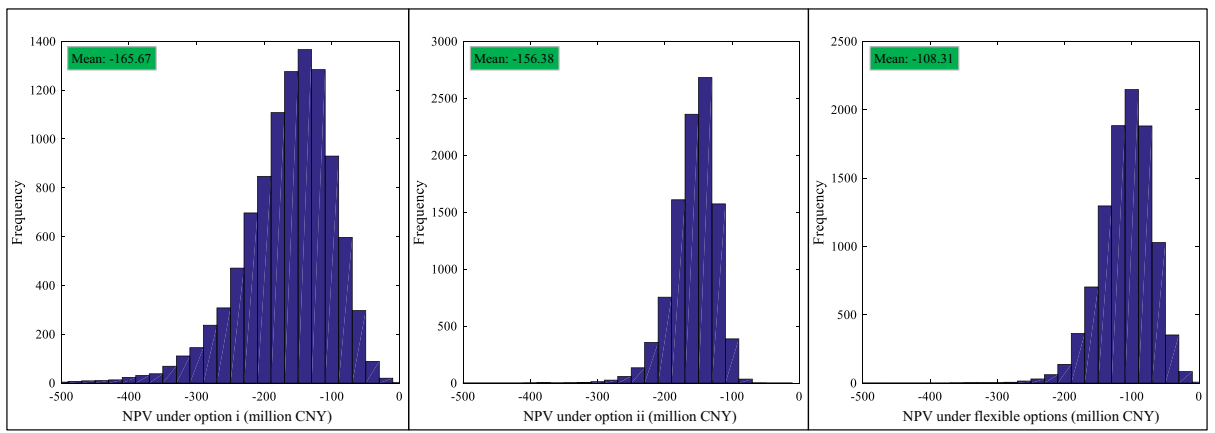

Fig. 5 NPV of integrated profits under different options. The NPV under option $\mathrm{i}$ is shown in the left panel; the NPV under option ii is shown in the middle panel; the NPV under the flexible options is shown in the right panel 


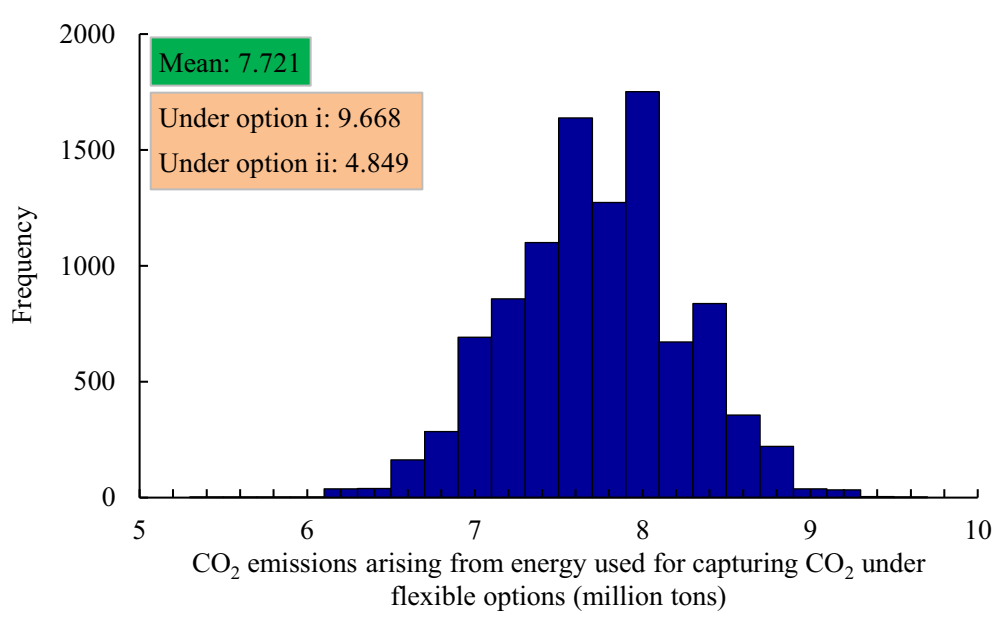

Fig. $6 \mathrm{CO}_{2}$ emissions arising from the energy used for capturing $\mathrm{CO}_{2}$ under different options. The data in the orange text box in the upper left corner of the figure are the $\mathrm{CO}_{2}$ emissions arising from the energy used for capturing $\mathrm{CO}_{2}$ when option $\mathrm{i}$ and option ii are executed during the three credit periods

\subsection{The $\mathrm{CO}_{2}$ emissions arising from energy used for $\mathrm{CO}_{2}$ capture under different options}

The $\mathrm{CO}_{2}$ emissions arising from energy used for $\mathrm{CO}_{2}$ capture under different options are shown in Fig. 6. Coal-fired power plants generate the highest $\mathrm{CO}_{2}$ emissions arising from energy used for $\mathrm{CO}_{2}$ capture when executing option i. Compared with option i, option ii yields $49.84 \%$ less $\mathrm{CO}_{2}$ emissions during the three crediting periods. In addition, under the principle of maximum profits, the $\mathrm{CO}_{2}$ emissions are $1.56-40.77 \%$ lower than those under option $\mathrm{i}$. This result shows that unless the CER price during the three crediting periods is always greater than the critical CER price, the integrated profits and $\mathrm{CO}_{2}$ emissions cannot be optimal at the same time.

\subsection{Sensitivity analysis}

There may be uncertainty in the CER price volatility, CER price drift rate, profits per megawatt hour, $\mathrm{CO}_{2}$ emission factor of coal-fired power plants and the $\mathrm{CM} \mathrm{CO}_{2}$ emission factor of the electricity system for various reasons. To analyse the impact of these uncertainties on the results, a sensitivity analysis is conducted with a $10 \%$ change in each variable.

\subsubsection{Impact on the critical CER price for option adjustment and probabilities of executing option ii}

The sensitivities of each key parameter's effects on the critical CER price for option adjustment and probabilities of executing option ii are shown in Figs. 7 and 8. Two opposite changes in the critical CER price and the probabilities will be contributed by an increment and a reduction in each variable. Next, we focus on the changes brought about by a reduction in each variable. The critical CER price has nothing to do with the real CER price (i.e. the CER price volatility and drift rate). However, the reduction in the drift rate results in a decline in actual CER prices, and it decreases operators' interest in option ii. The distribution of CER prices 


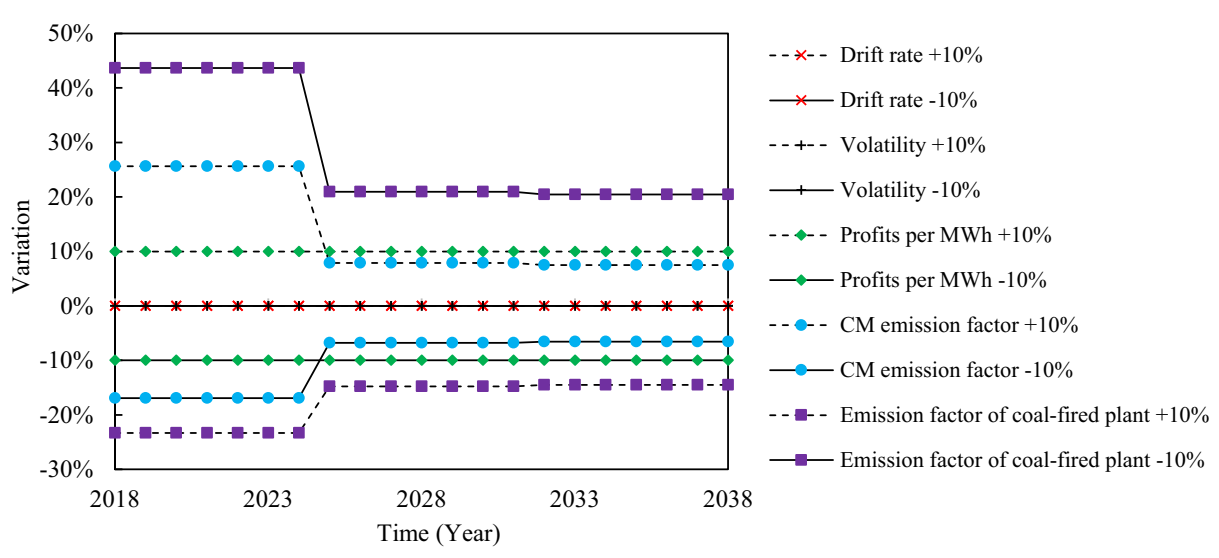

Fig. 7 Impact on critical CER price for option adjustment

becomes more concentrated with the decrease in volatility, which makes the probabilities of executing option ii decrease and then increase. The decline in the profit of electricity production leads to a strengthening of interest by companies to make option ii. The CM emission factor and the $\mathrm{CO}_{2}$ emission factor of coal-fired power plants will bring about opposite changes in the critical CER price and probabilities of executing option ii, especially during the first crediting period. Overall, most of the time, the options are primarily influenced by the $\mathrm{CO}_{2}$ emission factor of coal-fired power plants.

\subsubsection{Impact on the NPV of integrated profits under flexible options}

The impact on the NPV of integrated profits is shown in Fig. 9. Next, we also focus on the changes brought about by a reduction in each variable. The loss of profits from the CERs has a clear negative correlation with the drift rate, as does the NPV of integrated profits. The most intuitive effect of volatility on NPV is reflected in the concentration of the NPV distribution. Additionally, decreases in volatility do not affect the average NPV under both option i and option ii, but they result in a small decrease in the average NPV under the flexible options. The profits per megawatt hour have a significant impact on the NPV under option i. As a result, the

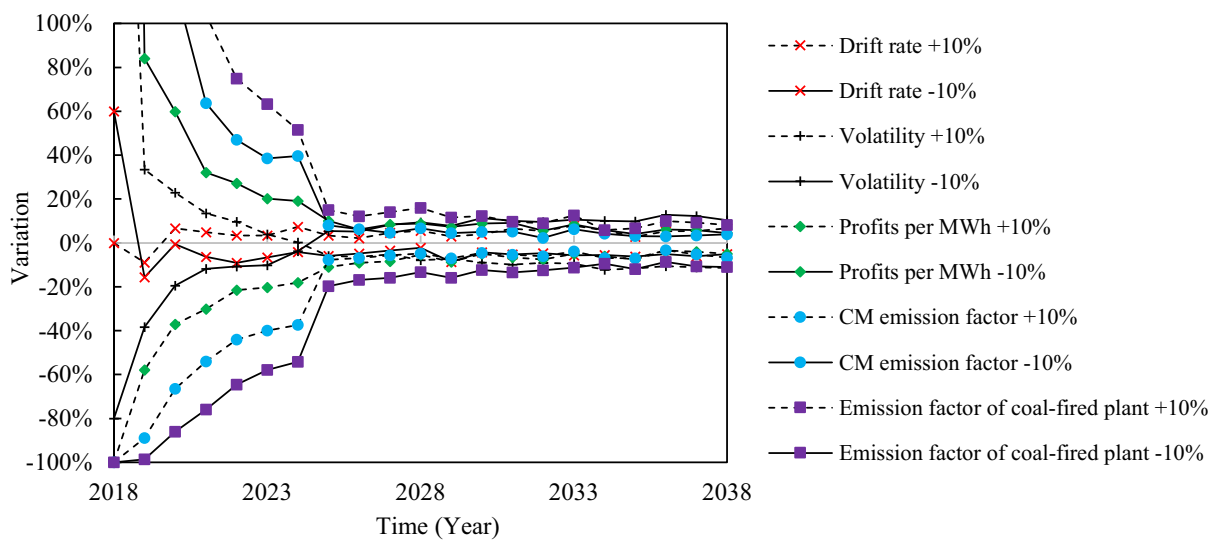

Fig. 8 Impact on the probability of executing option ii 


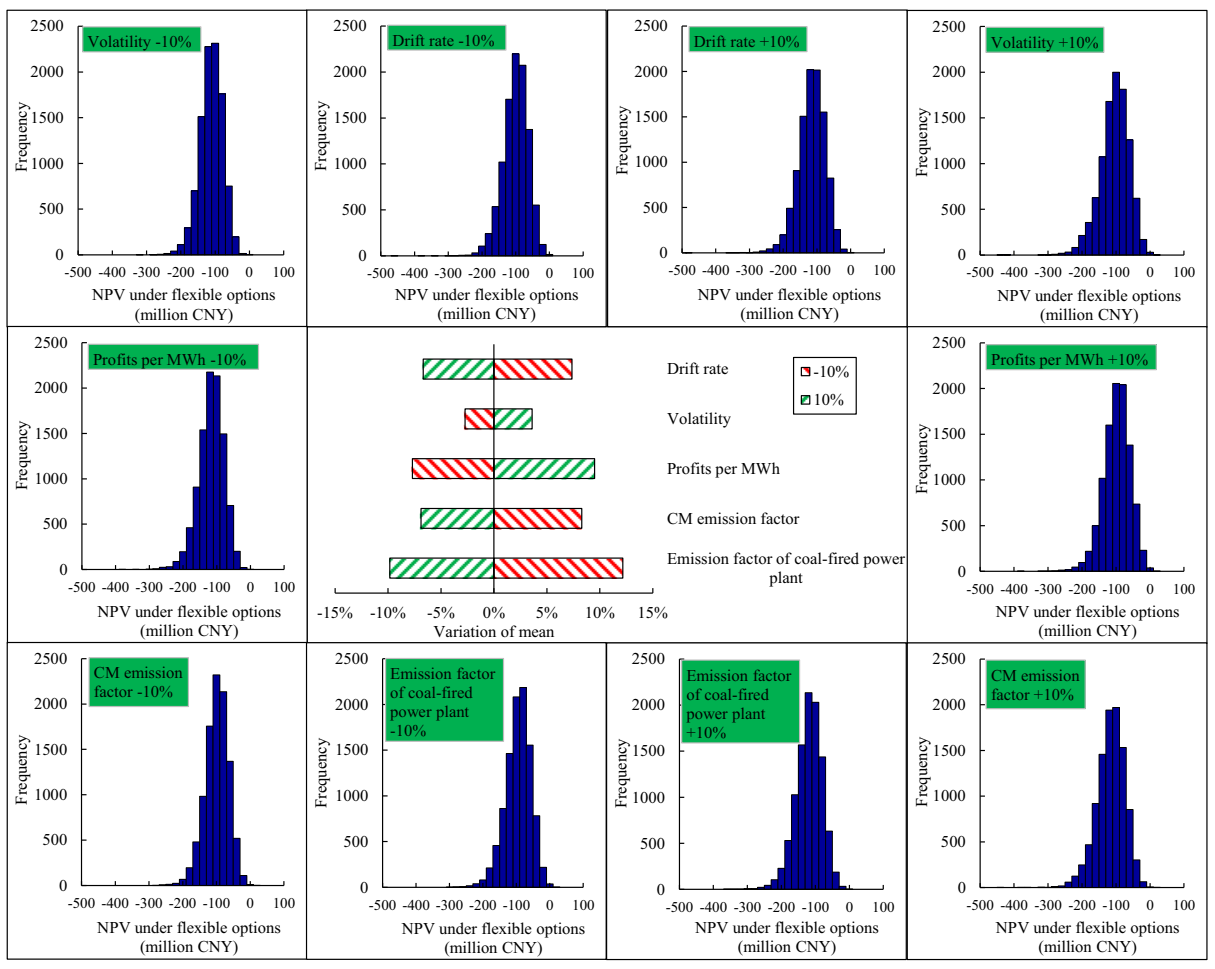

Fig. 9 Impact on the NPV of integrated profits under flexible options. The horizontal histogram in the middle shows changes in the mean of the NPV caused by changes in the variables

NPV under flexible options will generally decline as the profit of electricity production declines. The $\mathrm{CM} \mathrm{CO}_{2}$ emission factor and $\mathrm{CO}_{2}$ emission factor of coal-fired power plants play roles in option ii and option i, respectively. Their decrease will eventually increase the NPV under flexible options, but the $\mathrm{CO}_{2}$ emission factor of coal-fired power plants has a greater impact.

\subsubsection{Impact on $\mathrm{CO}_{2}$ emissions arising from the energy used for the $\mathrm{CO}_{2}$ capture}

The impact on the $\mathrm{CO}_{2}$ emissions arising from the energy used for $\mathrm{CO}_{2}$ capture is shown in Fig. 10. We also focus on the changes brought about by a reduction in each variable. The change in $\mathrm{CO}_{2}$ emissions is not as obvious as that of the NPV of integrated profits. The decrease in the $\mathrm{CO}_{2}$ emission factor of coal-fired power plants and the $\mathrm{CM} \mathrm{CO}_{2}$ emission factor results in a reduction in $\mathrm{CO}_{2}$ emissions, which are determined by the joint effect of the change in the emission factor and the probability of executing each option. For the other three variables, changes in the $\mathrm{CO}_{2}$ emissions arising from the energy used for the $\mathrm{CO}_{2}$ capture are dependent on only the probability of executing each option.

\subsection{Discussion}

Thorbjörnsson (2014) pointed out that the coal-fired power plants will consume 20-35\% more coal to supply the same amount of electricity under CCS than they would globally without 


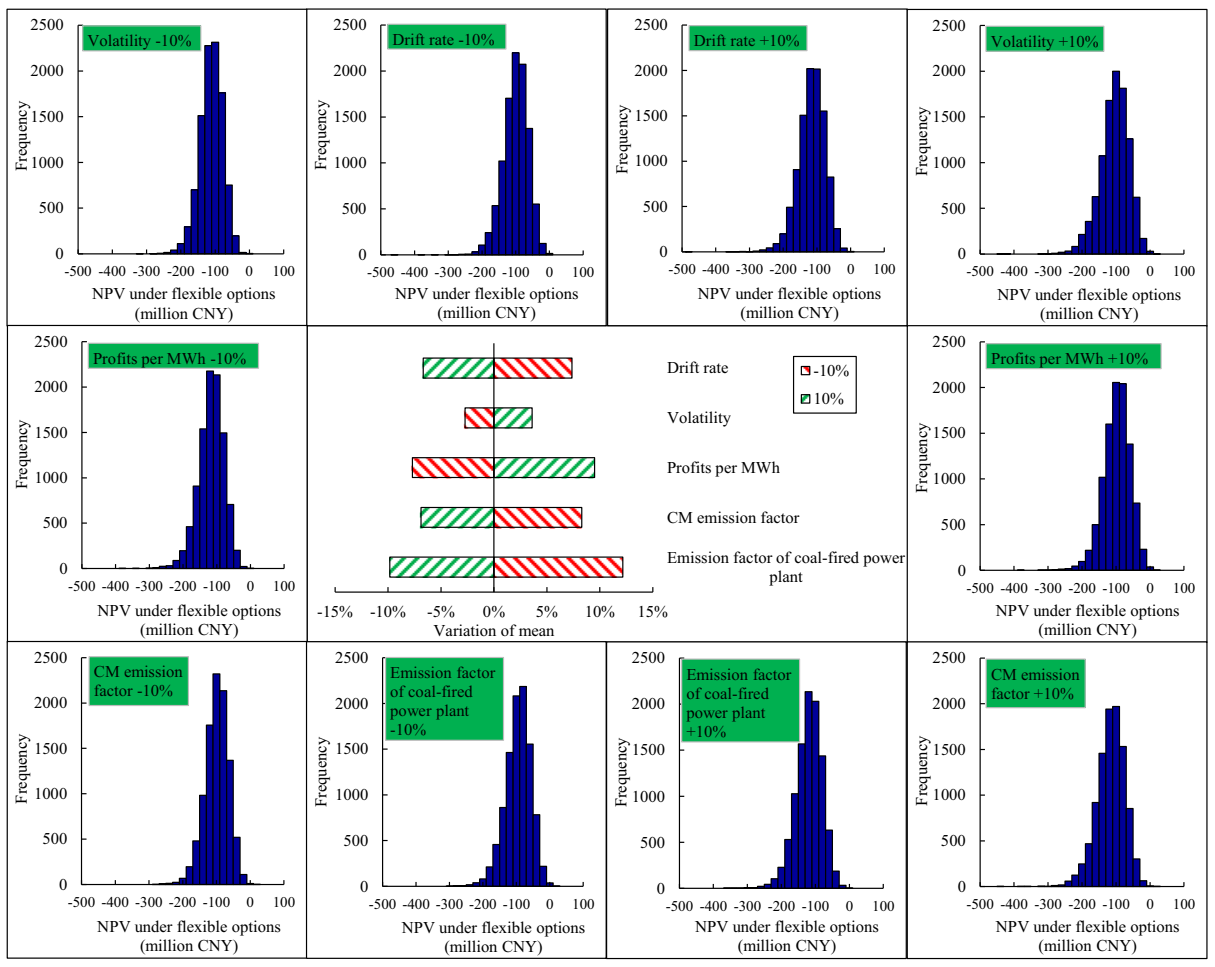

Fig. 10 Impact on the $\mathrm{CO}_{2}$ emissions arising from the energy used for $\mathrm{CO}_{2}$ capture under flexible options. The horizontal histogram in the middle shows changes in the mean of the $\mathrm{CO}_{2}$ emissions from the consumed energy

CCS. This result is based on the assumption that the energy consumption of the CCS is all provided by coal. From the research results of this paper, this statement is not sufficiently comprehensive. Operators of CCS will implement flexible options for providing energy in the future. Compared with option i, option ii indirectly increases the consumption of low-carbon electricity. For a 600-MW plant in China, compared with option i, flexible options increase the emission reduction effect by $0.53-13.7 \%$ during the three crediting periods (from 2018 to 2038). If $2.2 \%$ of all installed capacity above $30 \mathrm{MW}$ is equipped with CCS in China, which would meet the emission reduction requirements for 2018-2038 of the power sector with CCS (approximately 1 billion tons) (CoalSwarm/SierraClub/Greenpeace 2018; IEA 2015; IEA 2016a; IEA 2018), the emission reduction caused by the flexible options would be 5-130 million tons. From the perspective of developing countries around the world, the contribution of flexible options towards mitigating climate change would be even greater. In addition, the faster the development of low-carbon electricity (nuclear power, wind power, solar power, etc.) is, the earlier the adjustment from option i to option ii. From this perspective, CCS and lowcarbon electricity will not be antagonistic but will instead reinforce and promote the development of low-carbon power systems in developing countries. Therefore, we suggest that more attention should be paid to the flexible options to provide energy for capturing $\mathrm{CO}_{2}$ under the CDM. There is no doubt that a high CER price is essential to expand the positive effects of the flexible options. Thus, the first group to focus on flexible options should be international climate change policy negotiators and policymakers, who should work towards stricter 
emission reduction policies. It is believed that the phenomenon of low CER prices due to differences in climate change negotiations is only temporary. Under stricter emission reduction policies, developed countries need to purchase more CERs from developing countries through the CDM, which will push up the price of CERs. It is the operators of coal-fired power plants with CCS who directly decide whether to implement flexible options. To maximize revenue, operators should be informed of the options to be implemented based on the evaluation methods and framework constructed in this study. The research framework and methods are applicable not only to China's coal-fired power plants with CCS but also to those in all developing countries.

The positive effects of flexible options may be accompanied by some negative effects. The stability of a power system is the foundation of social and economic development (Darwish et al. 1977). Although the option adjustment for every coal-fired power plant will not have a strong impact on the stability of the power system due to differences in adjustment time (critical price), some impact is still likely to occur. Therefore, coal-fired power plants should make a pre-judgement about the option and communicate with the administration of the power system in a timely manner. In addition, the operation and planning of the power system should prepare for a situation in which coal-fired power plants will (want to) adjust the option. Flexible power system control mechanisms and the reasonable planning of the installed capacity may be regarded as good choices.

\section{Conclusions}

This study evaluated the options for providing energy to capture $\mathrm{CO}_{2}$ in coal-fired power plants under the CDM in developing countries and assessed the corresponding economic and emission reduction effects of coal-fired power plants with CCS. Compared with the means proposed in previous studies, involving a flexible capture rate to maximize the economic efficiency of $\mathrm{CO}_{2}$ capture, this study proposes another method from a new perspective. Because of the current extremely low CER prices, coal-fired power plants will implement option i. However, with the further increase in pressure to reduce emissions, adjustments from option i to option ii are likely to emerge. The critical CER price for option adjustment is not high, with values of $98 \mathrm{CNY} /$ ton, $56 \mathrm{CNY} /$ ton and $55 \mathrm{CNY} /$ ton during the first, second and third crediting periods in China, respectively. Compared with option i and option ii, the flexible options yield more profits because the average NPV of coal-fired power plants (600 MW in China) with CCS is increased by 57.36 and 48.07 million CNY, respectively. In addition, compared with option i, flexible options increase the emission reduction effect by $0.53-13.7 \%$ during the three crediting periods.

In addition, we have discussed and refined the systematic global strategies for expanding the positive effects of flexible options and avoiding the disadvantages of flexible options. If large-scale coal-fired power plants (above $30 \mathrm{MW}$ ) are equipped with CCS in developing countries, which would meet the emission reduction requirements of the power sector with CCS, the flexible options will increase the emission reduction by 5-130 million tons. In addition, flexible options will also promote the optimization of power systems in developing countries. Therefore, international climate change policy negotiators and policymakers should give full recognition and attention to the option to provide energy for capturing $\mathrm{CO}_{2}$ under the $\mathrm{CDM}$ and its positive impact. The priority for expanding the positive effects of flexible options is for international climate change policy negotiators and policymakers to formulate stricter 
international emission reduction policies. We believe that a high CER price is essential to expand the advantage of flexible options. However, the stability of the power system will be more or less affected by flexible options. A good communication and coordination mechanism between the coal-fired power plant and the administration of the power system is necessary to ensure the smooth implementation of flexible options.

Judging whether to make an option adjustment is based on the results of scientific calculations. This proposed method is suitable for evaluating the option to provide energy for capturing $\mathrm{CO}_{2}$ in developing countries under the CDM. In addition, the differences in the amount of CERs caused by the option adjustment will affect the investment decision with regard to CCS technology, which is not considered in the current research (Zhang et al. 2014; Zhou et al. 2010). We believe that our analysis can provide support for more comprehensive research on CCS technology investment decisions in the future.

Acknowledgments We appreciate our colleagues' support and help from the BIT Center for Energy and Environmental Policy Research. We also would like to thank Dr. Xian Zhang of the Administrative Centre for China's Agenda 21.

Funding information

This work received financial support from China's National Key R\&D Program (2016YFA0602603) and the National Natural Science Foundation of China (Nos. 71521002 and 71642004).

\section{Appendix}

The calculation of the operating margin $(\mathrm{OM}) \mathrm{CO}_{2}$ emission factor and the build margin (BM) $\mathrm{CO}_{2}$ emission factor reference the method used in China. The data after 2016 are obtained from "China Energy and Electricity Outlook" (State Grid Energy Research Institute 2017).

The calculation method for the combined margin $\mathrm{CO}_{2}$ emission factor in year $t$ is as follows:

$$
e f_{\text {grid.CM.t }}=i f\left(t<2025,50 \% \cdot e f_{\text {grid.OM.t }}+50 \% \cdot e f_{\text {grid.BM.t }}, 25 \% \cdot e f_{\text {grid.OM.t }}+75 \% \cdot e f_{\text {grid.BM.t. }}\right)
$$

\section{(1). $\mathrm{OM} \mathrm{CO}_{2}$ emission factor}

In reference to the current method adopted in China (NDRC 2017), the $\mathrm{OM} \mathrm{CO}_{2}$ emission factor should be the average of the last 3 years before the start of each crediting period. In addition, when the ex-ante option (which has been defined in the tool to calculate the emission factor for an electricity system (version 05.0)) is chosen, the emission factor is determined for each crediting period, making monitoring and recalculation during the crediting period unnecessary. This study assumes that the station service power consumption rate for coal-fired power plants and natural gas-fired power plants are equal. Power generation can be used as a substitute for the power supply to calculate the $\mathrm{OM} \mathrm{CO} 2$ emission factor. In addition, the proportions of natural gas-fired power generation (less than 5\%) and oil-fired power generation (less than 1\%) are both small. The annual $\mathrm{OM} \mathrm{CO}_{2}$ emission factor is calculated according to the year's coal-fired power generation, natural gas-fired power generation and the emission factors of coalfired power plants and natural gas-fired power plants, as shown in Table 2. The $\mathrm{CO}_{2}$ 
Table 2 Parameters and data required to calculate the $\mathrm{OM}$ emission factor for each crediting period. These parameters and data are obtained from the State Grid Energy Research Institute (2017), Editorial Board of the China Electric Power Yearbook (2006-2017), IPCC (2005) and NDRC (2014). The data in the table in italics, boldface and bold italic emphases are used to calculate the OM emission factors of the first, second and third crediting periods, respectively

\begin{tabular}{|c|c|c|c|c|}
\hline \multirow{2}{*}{$\begin{array}{l}\text { Time } \\
\text { (year) }\end{array}$} & \multicolumn{2}{|l|}{ Coal-fired power } & \multicolumn{2}{|c|}{ Natural gas-fired power } \\
\hline & $\begin{array}{l}\text { Power } \\
\text { generation } \\
\text { (billion MWh) }\end{array}$ & $\begin{array}{l}\text { Emission } \\
\text { factor } \\
\text { (tons/MWh) }\end{array}$ & $\begin{array}{l}\text { Power } \\
\text { generation } \\
\text { (billion MWh) }\end{array}$ & $\begin{array}{l}\text { Emission } \\
\text { factor } \\
\text { (tons/MWh) }\end{array}$ \\
\hline 2015 & 3.90 & 0.8372 & 0.17 & 0.3710 \\
\hline 2016 & 3.91 & 0.8313 & 0.19 & 0.3710 \\
\hline 2017 & 4.32 & 0.8258 & 0.25 & 0.3710 \\
\hline 2022 & 4.45 & 0.8037 & 0.40 & 0.3710 \\
\hline 2023 & 4.52 & 0.8001 & 0.43 & 0.3710 \\
\hline 2024 & 4.59 & 0.7966 & 0.44 & 0.3710 \\
\hline 2029 & 4.37 & 0.7814 & 0.57 & 0.3710 \\
\hline 2030 & 4.25 & 0.7787 & 0.59 & 0.3710 \\
\hline 2031 & 4.15 & 0.7762 & 0.61 & 0.3710 \\
\hline
\end{tabular}

Table 3 Parameters and data required to calculate the BM emission factor for each crediting period. These parameters and data are obtained from the State Grid Energy Research Institute (2017), Editorial Board of the China Electric Power Yearbook (2006-2017), IPCC (2005) and NDRC (2014). The data in the table in italics are used to calculate the BM emission factor of the first crediting period. The data in the table in boldface are used to calculate the BM emission factor of the second and third crediting periods

\begin{tabular}{|c|c|c|c|c|}
\hline $\begin{array}{l}\text { Time } \\
\text { (year) }\end{array}$ & $\begin{array}{l}\text { Installed } \\
\text { capacity of } \\
\text { thermal } \\
\text { plants } \\
\text { (thousand } \\
\text { gigawatts) }\end{array}$ & $\begin{array}{l}\text { Total } \\
\text { installed } \\
\text { capacity } \\
\text { (thousand } \\
\text { gigawatts) }\end{array}$ & $\begin{array}{l}\text { Emission factor } \\
\text { of the optimal } \\
\text { efficiency for } \\
\text { coal-fired pow- } \\
\text { er plants } \\
\text { (tons/MWh) }\end{array}$ & $\begin{array}{l}\text { Emission factor } \\
\text { of the optimal } \\
\text { efficiency for } \\
\text { natural gas- } \\
\text { fired power } \\
\text { plants } \\
\text { (tons/MWh) }\end{array}$ \\
\hline 2014 & 8.89 & 13.70 & / & / \\
\hline 2015 & 9.66 & 15.25 & / & / \\
\hline 2016 & 10.13 & 16.46 & / & / \\
\hline 2017 & 10.48 & 17.78 & 0.7598 & 0.3413 \\
\hline 2019 & 10.87 & 19.39 & / & I \\
\hline 2020 & 11.37 & 20.55 & I & I \\
\hline 2021 & 11.52 & 21.46 & I & I \\
\hline 2022 & 11.77 & 22.56 & I & I \\
\hline 2023 & 12.11 & 23.60 & I & I \\
\hline 2024 & 12.41 & 24.69 & 0.7328 & 0.3413 \\
\hline
\end{tabular}

Table $4 \mathrm{CM} \mathrm{CO}_{2}$ emission factor (unit: tons/MWh). The data in the table in italics, boldface and bold italic emphases are the OM emission factor, BM emission factor and CM emission factor of the first, second and third crediting periods, respectively

\begin{tabular}{llllllll}
\hline Time (year) & $e f_{\text {grid. }}$.M. $t$ & $e f_{\text {grid. } B M . t}$ & $e f_{\text {grid. } C M . t}$ & Time (year) & $e f_{\text {grid. } . M . t}$ & $e f_{\text {grid. BM. } t}$ & $e f_{\text {grid. } C M . t}$ \\
\hline 2018 & 0.8097 & 0.2919 & 0.5508 & $\mathbf{2 0 2 9}$ & $\mathbf{0 . 7 6 3 6}$ & $\mathbf{0 . 2 0 7 5}$ & $\mathbf{0 . 3 4 6 5}$ \\
2019 & 0.8097 & 0.2919 & 0.5508 & $\mathbf{2 0 3 0}$ & $\mathbf{0 . 7 6 3 6}$ & $\mathbf{0 . 2 0 7 5}$ & $\mathbf{0 . 3 4 6 5}$ \\
2020 & 0.8097 & 0.2919 & 0.5508 & $\mathbf{2 0 3 1}$ & $\mathbf{0 . 7 6 3 6}$ & $\mathbf{0 . 2 0 7 5}$ & $\mathbf{0 . 3 4 6 5}$ \\
2021 & 0.8097 & 0.2919 & 0.5508 & 2032 & $\mathbf{0 . 7 2 9 3}$ & $\mathbf{0 . 2 0 7 5}$ & $\mathbf{0 . 3 3 7 9}$ \\
2022 & 0.8097 & 0.2919 & 0.5508 & 2033 & $\mathbf{0 . 7 2 9 3}$ & $\mathbf{0 . 2 0 7 5}$ & $\mathbf{0 . 3 3 7 9}$ \\
2023 & 0.8097 & 0.2919 & 0.5508 & 2034 & $\mathbf{0 . 7 2 9 3}$ & $\mathbf{0 . 2 0 7 5}$ & $\mathbf{0 . 3 3 7 9}$ \\
2024 & 0.8097 & 0.2919 & 0.5508 & 2035 & $\mathbf{0 . 7 2 9 3}$ & $\mathbf{0 . 2 0 7 5}$ & $\mathbf{0 . 3 3 7 9}$ \\
$\mathbf{2 0 2 5}$ & $\mathbf{0 . 7 6 3 6}$ & $\mathbf{0 . 2 0 7 5}$ & $\mathbf{0 . 3 4 6 5}$ & 2036 & $\mathbf{0 . 7 2 9 3}$ & $\mathbf{0 . 2 0 7 5}$ & $\mathbf{0 . 3 3 7 9}$ \\
$\mathbf{2 0 2 6}$ & $\mathbf{0 . 7 6 3 6}$ & $\mathbf{0 . 2 0 7 5}$ & $\mathbf{0 . 3 4 6 5}$ & 2037 & $\mathbf{0 . 7 2 9 3}$ & $\mathbf{0 . 2 0 7 5}$ & $\mathbf{0 . 3 3 7 9}$ \\
$\mathbf{2 0 2 7}$ & $\mathbf{0 . 7 6 3 6}$ & $\mathbf{0 . 2 0 7 5}$ & $\mathbf{0 . 3 4 6 5}$ & $\mathbf{2 0 3 8}$ & $\mathbf{0 . 7 2 9 3}$ & $\mathbf{0 . 2 0 7 5}$ & $\mathbf{0 . 3 3 7 9}$ \\
$\mathbf{2 0 2 8}$ & $\mathbf{0 . 7 6 3 6}$ & $\mathbf{0 . 2 0 7 5}$ & $\mathbf{0 . 3 4 6 5}$ & & & & \\
\hline
\end{tabular}


emission factor of natural gas-fired power plants remains unchanged at 0.371 tons/MWh (IPCC 2005).

$$
e f_{\text {grid.OM.k }}=\frac{\sum_{t^{\prime}=k_{1}-3}^{k_{1}-1}\left(\frac{c g_{\text {coal }} \cdot e f_{\text {coal }}^{\prime}+g g_{\text {gas }} \cdot e f_{\text {gas }}^{\prime}}{c g_{\text {coal }}+g g_{\text {gas }}}\right)_{t^{\prime}}}{3}
$$

where $e f_{\text {grid. }} O$ M. $k_{k}$ denotes the $\mathrm{OM} \mathrm{CO}_{2}$ emission factor in crediting period $k(k=1,2,3)$ (tons/MWh); $k_{1}$ denotes the initial year of each crediting period (year); $t$ denotes the past 3 years before the start of each crediting period (year); $c g_{\text {coal }}$ denotes coal-fired power generation (billion $\mathrm{MWh}$ ); $g g_{\text {gas }}$ denotes natural gas-fired power generation (billion $\mathrm{MWh}) ; e f_{\text {coal }}^{\prime}$ denotes the average $\mathrm{CO}_{2}$ emission factor of the total coal-fired power plants in the electricity system, $e f_{\text {coal }}^{\prime}=2.64 \cdot(0.3788-0.0257 \ln (t-2004))$ (tons/MWh); and $e f_{\text {gas }}^{\prime}$ denotes the average $\mathrm{CO}_{2}$ emission factor of the total natural gas-fired power plants in the electricity system (0.371) (tons/MWh).

\section{(2). $\mathrm{BM} \mathrm{CO}_{2}$ emission factor}

The calculation of the $\mathrm{BM} \mathrm{CO}_{2}$ emission factor for each crediting period is based on option 1 (which has been defined in the tool to calculate the emission factor for an electricity system (version 05.0)). For the first and second crediting periods, the $\mathrm{BM} \mathrm{CO}_{2}$ emission factor is calculated based on the data from the year before each crediting period. For the third crediting period, the $\mathrm{BM} \mathrm{CO}_{2}$ emission factor calculated for the second crediting period should be used. Therefore, we only calculated the $\mathrm{BM} \mathrm{CO}_{2}$ emission factor of the first and second crediting periods. We chose coal-fired power plants and natural gas-fired power plants to represent thermal power plants. In referencing the current method adopted in China (NDRC 2017), the calculation process for the $\mathrm{BM} \mathrm{CO}_{2}$ emission factor is as follows:

1) Using the datum from the last year to calculate the proportion of $\mathrm{CO}_{2}$ emissions from coal-fired power generation and natural gas-fired power generation.

2) The $\mathrm{CO}_{2}$ emission factor of thermal power generation is calculated based on the abovementioned proportion and the emission factor of the most advanced commercialized technology. We assume that the $\mathrm{CO}_{2}$ emission factor of the advanced power plants is $8 \%$ lower than the average.

3) Then, the BM emission factor can be obtained by multiplying the emission factor of thermal power by the proportion of thermal power in the newly added $20 \%$ installed capacity of the electricity system.

$$
e f_{\text {grid.BM.k }}=\frac{n i c_{\text {coal }, k_{1}}+n i c_{\text {gas }, k_{1}}}{n i c_{\text {total }, k_{1}}}\left(\frac{c g_{\text {coal }} \cdot e f_{c o a l}^{\prime} \cdot e f_{c o a l}^{o e}+g g_{\mathrm{gas}} \cdot e f_{\mathrm{gas}}^{\prime} \cdot e f_{\mathrm{gas}}^{o e}}{c g_{\text {coal }} \cdot e f_{\text {coal }}^{\prime}+g g_{\mathrm{gas}} \cdot e f_{\mathrm{gas}}^{\prime}}\right)_{k_{1}-1}
$$

where $e f_{\text {grid. } B M . k}$ denotes the $\mathrm{BM} \mathrm{CO} \mathrm{CO}_{2}$ emission factor for crediting period $k(k=1,2)$ (tons/MWh); $n i c_{\text {total. } k_{1}}$ denotes the total newly installed capacity over the time range that 
reaches or exceeds $20 \%$ of the installed capacity of the previous year (MW); $n i c_{\text {coal. } k_{1}}$ denotes

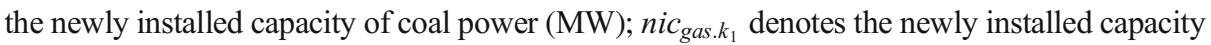
of natural gas-fired power (MW); ef coal denotes the $\mathrm{CO}_{2}$ emission factor of the optimal efficiency of coal-fired power plants (tons/MWh); and ef gas denotes the $\mathrm{CO}_{2}$ emission factor of the optimal efficiency for natural gas-fired power plants (tons/MWh).

Open Access This article is distributed under the terms of the Creative Commons Attribution 4.0 International License (http://creativecommons.org/licenses/by/4.0/), which permits unrestricted use, distribution, and reproduction in any medium, provided you give appropriate credit to the original author(s) and the source, provide a link to the Creative Commons license, and indicate if changes were made.

\section{References}

Abdi A, Taghipour S, Khamooshi H (2018) A model to control environmental performance of project execution process based on greenhouse gas emissions using earned value management. Int J Proj Manag 36:397-413. https://doi.org/10.1016/j.ijproman.2017.12.003

Abdul Manaf N, Qadir A, Abbas A (2016) Temporal multiscalar decision support framework for flexible operation of carbon capture plants targeting low-carbon management of power plant emissions. Appl Energy 169:912-926. https://doi.org/10.1016/j.apenergy.2016.02.052

Arce A, Mac Dowell N, Shah N, Vega LF (2012) Flexible operation of solvent regeneration systems for $\mathrm{CO}_{2}$ capture processes using advanced control techniques: towards operational cost minimisation. Int $\mathrm{J}$ Greenhouse Gas Control 11:236-250. https://doi.org/10.1016/j.ijggc.2012.09.004

Arranz AM (2016) Hype among low-carbon technologies: carbon capture and storage in comparison. Glob Environ Chang 41:124-141. https://doi.org/10.1016/j.gloenvcha.2016.09.001

Broek MVD, Hoefnagels R, Rubin E, Turkenburg W, Faaij A (2009) Effects of technological learning on future cost and performance of power plants with $\mathrm{CO}_{2}$ capture. Prog Energy Combust Sci 35:457-480. https://oi. org/10.1016/j.pecs.2009.05.002

Chalmers H, Lucquiaud M, Gibbins J, Leach M (2009) Flexible operation of coal fired power plants with postcombustion capture of carbon dioxide. Int J Environ Eng 135:449-458. https://doi.org/10.1061 /(ASCE)EE.1943-7870.0000007

Chou JS (2011) Cost simulation in an item-based project involving construction engineering and management. Int J Proj Manag 29:706-717. https://doi.org/10.1016/j.ijproman.2010.07.010

CoalSwarm/SierraClub/Greenpeace (2018) Boom and bust 2018: tracking the global coal plant pipeline. http://www.indiaenvironmentportal.org.in/files/file/boomandbust_2018_coalreport.pdf. Accessed 10 November 2018

Company \& McKinsey (2008) Carbon capture and storage: assessing the economics. http://www. indiaenvironmentportal.org.in/files/CCS_Assessing_the_Economics.pdf. Accessed 27 March 2018

Darwish M, Fantin J, Grateloup G (1977) On the stability of large-scale power systems. J Cybernetics 7:159-167. https://doi.org/10.1080/01969727708927556

Dueñas P, Reneses J, Barquín J (2011) Dealing with multi-factor uncertainty in electricity markets by combining Monte Carlo simulation with spatial interpolation techniques. IET Gener Transm Distrib 5:323-331. https://doi.org/10.1049/iet-gtd.2010.0264

Editorial Board of the China Electric Power Yearbook (2006-2017) China electric power yearbook 2006-2017. China power press, Beijing (In Chinese)

Editorial Board of the China Electric Power Yearbook (2008-2017) China electric power yearbook 2008-2017. China power press, Beijing (In Chinese)

Feron PHM (2006) Progress in post-combustion $\mathrm{CO}_{2}$ capture. Paper presented at the $\mathrm{CO}_{2} \mathrm{NET}_{\text {EAST }}$ workshop, Zagreb. https://www.geology.sk/co2neteast/documents/workshop_zagreb/Paul_Feron-CASTOR-Progress in_post-combustion_CO2_capture.pdf. Accessed 12 March 2018

Fuss S, Szolgayova J, Obersteiner M, Gusti M (2008) Investment under market and climate policy uncertainty. Appl Energy 85:708-721. https://doi.org/10.1016/j.apenergy.2008.01.005

Global CCS Institute (2011) Developing CCS projects under the lean Development Mechanism. http://hub. globalccsinstitute.com/sites/default/files/publications/25786/manual-developing-ccs-projects-under-cdm. pdf. Accessed 5 March 2018

Haefeli S, Bosi M, Philibert C (2004) Carbon dioxide capture and storage issues - accounting and baselines under the United Nations Framework Convention on Climate Change. http://pdfs.semanticscholar. org/eddd/8649e73d4eae9ac78a88aad4305c97af0c1c.pdf. Accessed 6 March 2018 
Huaneng Power International Inc. (2016-2017) Huaneng Power International Inc annual report 2015-2017. (In Chinese). http://www.hpi.com.cn/reportYA/publish.aspx\#. Accessed 15 November 2017

IEA (2008) $\mathrm{CO}_{2}$ capture and storage: a key carbon abatement option. http://www.iea. org/publications/freepublications/publication/CCS_2008.pdf. Accessed 4 November 2018

IEA (2015) World Energy Outlook 52015. https://www.iea.org/publications/freepublications/publication/WEO2015.pdf. Accessed 15 January 2019

IEA (2016a) 20 years of carbon capture and storage-accelerating future deployment. https://www.iea. org/publications/freepublications/publication/20-years-of-carbon-capture-and-storage.html. Accessed 15 November 2018

IEA (2016b)World Energy Outlook 2016. https://webstore.iea.org/download/summary/202?fileName=EnglishWEO-2016-ES.pdf. Accessed 15 November 2018

IEA (2017) $\mathrm{CO}_{2}$ emissions from fuel combustion 2017. http://www.iea.org/publications/ freepublications/publication/CarbonCaptureandStorageThesolutionfordeepemissionsreductions.pdf. Accessed 4 November 2018

IEA (2018) $\mathrm{CO}_{2}$ emissions from fuel combustion database. http://wds.iea.org/wds/pdf/Worldco2 Documentation.pdf. Accessed 16 January 2019

IEAGHG (2005) Building the cost curves for $\mathrm{CO}_{2}$ storage: North America. http:/hub.globalccsinstitute. $\mathrm{com} /$ sites/default/files/publications/50831/2005-03-north-america-storage-cost-curves.pdf. Accessed 15 November 2018

IEAGHG (2007) ERM-carbon dioxide capture and storage in the clean development mechanism. http://www. ccsassociation.org/docs/2007/2007\%20TR2CCS\%20CDM\%20methodology\%20.pdf. Accessed 9 May 2018

Insley MC (2003) On the option to invest in pollution control under a regime of tradable emissions allowances. Can J Econ 36:860-883. https://doi.org/10.1111/1540-5982.t01-3-00004

Intercontinental Exchange (2018) ICE CER futures-emissions CER index. https://www.theice. com/marketdata/reports/94. Accessed 6 March 2018

IPCC (2005) IPCC special report on carbon dioxide capture and storage. Cambridge University Press, Cambridge and New York, NY

IPCC (2014) Climate change 2014: mitigation of climate change. Cambridge University Press, Cambridge and New York, NY

IPCC (2015) Climate change 2014: synthesis report summary for policymakers. Cambridge University Press, Cambridge and New York, NY

Li J (2010) Options for introducing $\mathrm{CO}_{2}$ capture and capture readiness for coal fired power plants in China. Imperial College London

Liu J, Jin F, Xie Q, Skitmore M (2017) Improving risk assessment in financial feasibility of international engineering projects: a risk driver perspective. Int J Proj Manag 35:204-211. https://doi.org/10.1016/j. ijproman.2016.11.004

Mi Z et al (2017a) Pattern changes in determinants of Chinese emissions. Environ Res Lett 12:1-10. https://doi. org/10.1088/1748-9326/aa69cf

$\mathrm{Mi} \mathrm{Z}$ et al (2017b) Chinese $\mathrm{CO}_{2}$ emission flows have reversed since the global financial crisis. Nat Commun 8:110. https://doi.org/10.1038/s41467-017-01820-w

NDRC (2014) Interim measures for the promotion and management of energy-saving and low-carbon technologies. (In Chinese). http://www.ndrc.gov.cn/zcfb/zcfbtz/201401/t20140110_575363.html. Accessed 1 March 2018

NDRC (2017) 2016 China's regional grid baseline emission factor (draft). (In Chinese). http://qhs.ndrc.gov. cn/gzdt/201704/t20170414_844347.html. Accessed 6 March 2018

Park T, Kim C, Kim H (2014) A real option-based model to valuate CDM projects under uncertain energy policies for emission trading. Appl Energy 131:288-296. https://doi.org/10.1016/j.apenergy.2014.06.040

Patino-Echeverri D, Hoppock DC (2012) Reducing the average cost of $\mathrm{CO}_{2}$ capture by shutting-down the capture plant at times of high electricity prices. Int J Greenhouse Gas Control 9:410-418. https://oi. org/10.1016/j.ijggc.2012.04.013

Philibert C, Ellis J, Podkanski J (2007) Carbon capture and storage in the CDM. http://www.indiaenvironmentportal.org. in/content/252125/carbon-capture-and-storage-in-the-cdm/. Accessed 25 April 2018

Rubin ES, Davison JE, Herzog HJ (2015) The cost of $\mathrm{CO}_{2}$ capture and storage. Int J Greenhouse Gas Control 40: 378-400. https://doi.org/10.1016/j.ijggc.2015.05.018

State Grid Energy Research Institute (2017) China energy and electricity outlook. China electric power press, Beijing (In Chinese)

Stigson P, Hansson A, Lind M (2012) Obstacles for CCS deployment: an analysis of discrepancies of perceptions. Mitig Adapt Strat G1 17:601-619. https://doi.org/10.1007/s11027-011-9353-3

Supekar SD, Skerlos SJ (2015) Reassessing the efficiency penalty from carbon capture in coal-fired power plants. Environ Sci Technol 49:12576-12584. https://doi.org/10.1021/acs.est.5b03052 
Tang BJ, Zhou HL, Chen H, Wang K, Cao H (2017) Investment opportunity in China's overseas oil project: an empirical analysis based on real option approach. Energy Policy 105:17-26. https://doi.org/10.1016/j. enpol.2017.02.023

Thorbjörnsson A (2014) Carbon capture and storage: energy penalties and their impact on global coal consumption. Master thesis, Uppsala University

U.S.NRC (2018) Capacity factor (net). https://www.nrc.gov/reading-rm/basic-ref/glossary/capacity-factor-net. html. Accessed 12 September 2018

UNFCCC (2011) Carbon dioxide capture and storage in geological formations as clean development mechanism project activities. http://unfccc.int/resource/docs/2010/cmp6/eng/12a02.pdf. Accessed 6 March 2018

UNFCCC (2013) Proposed new carbon capture and storage baseline and monitoring methodology form (Version 02.0). http://cdm.unfccc.int/filestorage/e/x/t/extfile-20131007162532380-MethCCS_form09.pdf/MethCCS form09.pdf?t=aDJ8cDhjOHNofDAU_tPJP6TzKaAI6DWD93tu. Accessed 6 March 2018

UNFCCC (2015) Tool to calculate the emission factor for an electricity system (Version 05.0). http://cdm.unfccc. int/methodologies/PAmethodologies/tools/am-tool-07-v5.0.pdf. Accessed 15 March 2018

Viebahn P, Vallentin D, Höller S, Fischedick M (2012) Integrated assessment of CCS in the German power plant sector with special emphasis on the competition with renewable energy technologies. Mitig Adapt Strat Gl 17:707-730. https://doi.org/10.1007/s11027-011-9315-9

Vithayasrichareon P, MacGill IF (2012) A Monte Carlo based decision-support tool for assessing generation portfolios in future carbon constrained electricity industries. Energy Policy 41:374-392. https://doi. org/10.1016/j.enpol.2011.10.060

Wei YM, Mi ZF, Huang Z (2014) Climate policy modeling: an online SCI-E and SSCI based literature review. Omega-Int J Manage S 57:70-84. https://doi.org/10.1016/j.omega.2014.10.011

Wiley DE, Ho MT, Donde L (2011) Technical and economic opportunities for flexible $\mathrm{CO}_{2}$ capture at Australian black coal fired power plants. Energy Procedia 4:1893-1900. https://doi.org/10.1016/j.egypro.2011.02.068

ZEP (2011) The costs of $\mathrm{CO}_{2}$ capture: post-demonstration CCS in the EU. http://www.zeroemissionsplatform. eu/library/publication/166-zep-cost-report-capture.html. Accessed 27 October 2018

Zhang X, Wang X, Chen J, Xie X, Wang K, Wei Y (2014) A novel modeling based real option approach for CCS investment evaluation under multiple uncertainties. Appl Energy 113:1059-1067. https://doi.org/10.1016/j. apenergy.2013.08.047

Zhou W, Bing Z, Fuss S, Szolgayová J, Obersteiner M, Fei W (2010) Uncertainty modeling of CCS investment strategy in China's power sector. Appl Energy 87:2392-2400. https://doi.org/10.1016/j. apenergy.2010.01.013

Zhou W, Zhu B, Chen D, Zhao F, Fei W (2014) How policy choice affects investment in low-carbon technology: the case of $\mathrm{CO}_{2}$ capture in indirect coal liquefaction in China. Energy 73:670-679. https://doi.org/10.1016/j. energy.2014.06.068

Ziaii S, Rochelle GT, Edgar TF (2009) Dynamic modeling to minimize energy use for $\mathrm{CO}_{2}$ capture in power plants by aqueous monoethanolamine. Ind Eng Chem Res 48:6105-6111. https://doi.org/10.1021/ie801385q

Publisher's note Springer Nature remains neutral with regard to jurisdictional claims in published maps and institutional affiliations.

\section{Affiliations}

\section{Jiaquan $\mathrm{Li}^{1,2} \cdot$ Zhifu $\mathrm{Mi}^{3} \cdot$ Yi-Ming Wei ${ }^{2,4,5} \cdot$ Jingli Fan ${ }^{1,2} \cdot$ Yang Yang ${ }^{2,4,5,6} \cdot$ Yunbing Hou $^{1}$}

1 College of Resources and Safety Engineering, China University of Mining and Technology, Beijing (CUMTB), Beijing 100083, China

2 Center for Energy and Environmental Policy Research, Beijing Institute of Technology, Beijing 100081, China

3 The Bartlett School of Construction and Project Management, University College London, London WC1E 7HB, UK

4 School of Management and Economics, Beijing Institute of Technology, Beijing 100081, China

5 Beijing Key Lab of Energy Economics and Environmental Management, Beijing 100081, China

6 The Administrative Centre for China's Agenda 21, Beijing 100038, China 